\title{
AMINO ACID UPTAKE, CONTENT, AND METABOLISM BY NEURONAL AND GLIAL ENRICHED CELLULAR FRACTIONS FROM MOUSE CEREBELLUM ${ }^{1}$
}

\author{
RICHARD P. SHANK ${ }^{* 2}$ AND GRAHAM LEM. CAMPBELL \\ Department of Neurology, The Graduate Hospital, Philadelphia, Pennsylvania 19146 and * Department of Physiology, Temple \\ University School of Medicine, Philadelphia, Pennsylvania 19140
}

Received January 3, 1983; Revised June 13, 1983; Accepted July 5, 1983

\begin{abstract}
A series of biochemical determinations was performed on five cellular fractions obtained from the cerebellum of 8- to 14-day-old mice. Cerebellar tissue was dissociated by mild trypsinization and mechanical agitation. The dissociated cellular material was separated into five fractions using a scrics of continuous density gradients formed with Percoll. Three of the fractions were comprised primarily of cell bodies. One of these was dominated by cells having the size and morphological appearance of granule cells, and based on several criteria the other two were enriched in astrocyte cell bodies. Morphological analysis indicated that the remaining two fractions were enriched, respectively, in nerve terminals and large nucleated cell bodies.

'The uptake of 12 amino acids and 4 other metabolites by these cellular fractions was examined, and $K_{\mathrm{m}}$ and $V_{\max }$ values were determined for 10 of the compounds studied. High affinity transport carriers $\left(K_{\mathrm{m}} \sim 1\right.$ to $\left.20 \mu \mathrm{M}\right)$ for most of the compounds studied were evident in neuronal and astrocyte-enriched fractions; however, for glutamate and $\gamma$-aminobutyric acid (GABA) additional carriers with higher substrate affinities $\left(K_{\mathrm{m}} \sim 0.1\right.$ to $\left.0.3 \mu \mathrm{M}\right)$ were evident in the astrocyte-enriched fraction. The fraction enriched in granule cell bodies was distinguished by an exceptionally low uptake of GABA and citrate, and a comparatively low uptake of $\beta$-alanine, taurine, $\alpha$-ketoglutarate, and glutamate.

An analysis of the content of nine amino acids in the five fractions revealed that only glutamate, aspartate, and GABA were concentrated in the fraction enriched in nerve terminals. GABA was concentrated also in the fraction enriched in large cell bodies and was present at a low concentration in the fraction enriched in granule cell bodies. The other amino acids measured were distributed nearly evenly among the five fractions. Several differences in metabolic activity among the five fractions were observed. Radiolabel from several precursors was incorporated into GABA preferentially in the fractions enriched in large cell bodies and nerve terminals. In contrast, the accumulation of label in glutamine occurred preferentially in the fractions enriched in astrocytes and granule cell bodies. Labeling of alanine from $\left[{ }^{14} \mathrm{C}\right]$ pyruvate and of proline from $\left[{ }^{14} \mathrm{C}\right]$ ornithine was most prominent in the fractions enriched in astrocytes and granule cell bodies.
\end{abstract}

Glutamate, $\gamma$-aminobutyric acid (GABA), glycine, and possibly several other amino acids function as either neurotransmitters or neuromodulators in the CNS of vertebrates (Curlis and Johnson, 1974; Krnjevic, 1974;

\footnotetext{
${ }^{1}$ This research was supported by National Institutes of Health Grant NS16004, and was conducted in part at The Franklin Institute, Philadelphia, Pᄉ 19103.

${ }^{2}$ To whom correspondence should be sent, at his present address: Department of Biological Research, McNeil Pharmaceutical, Spring House, PA 19477.
}

Aprison et al., 1976; Davidson, 1976). At the present time only a few types of neurons have been shown with certainty to utilize a particular amino acid as a neurotransmitter, and current knowledge of the biochemical processes that underlie the transmitter function of these amino acids is rudimentary. Many questions relevant to the transmitter function of amino acids are difficult to answer from data obtained on structurally intact tissue. One way of circumventing some of the problems inherent with intact tissue preparations is to fractionate the tissue into cellular and subcellular components representative 
of specific types of cells. Taking this approach we have conducted a series of biochemical experiments on five fractions of cellular material obtained from the cerebellum of 8- to 14-day-old mice. The cerebellum was chosen in part because of the evidence that amino acid neurotransmitters are predominant in this tissue. Eight- to 14day-old mice were selected because the cerebellum at this age provided an optimal yield of different populations of viable nucleated cell bodies as well as a sufficient amount of synaptosomal material for biochemical analyses.

In this study we have obtained information relevant to five issues: (1) which amino acids function as neurotransmitters in the cerebellum, (2) the involvement of astrocytes in the inactivation of amino acid neurotransmitters, (3) the metabolic precursors of the neurolransmitter pools of glutamate and GABA, (4) the basis for the metabolic compartmentation of glutamate and related amino acids that is characteristic of CNS tissues, and (5) the relative contribution of amino acid transport in cell bodies and their corresponding nerve terminals.

\section{Materials and Methods}

Method for obtaining cerebellar material enriched in cell bodies and nerve terminals. The animals were ICR mice ranging in age from 8 to 14 days. In preliminary experiments mice ranging in age from newborn to adult were used for biochemical analysis. For any single experiment the cerebellum of 2 to 20 mice was excised and immersed in Roswell Park Memorial Institute Medium (RPMI) 1640 (Grand Island Biological Co. (GIBCO), Grand Island, NY) containing DNase $(0.0025 \% \mathrm{w} / \mathrm{v})$. The tissue then was treated by a method similar to that described by Campbell et al. (1977) to disrupt the tissue and disperse the cells. Briefly, each cerebellum was cut into several pieces and incubated for $10 \mathrm{~min}$ at 21 to $23^{\circ} \mathrm{C}$ in an RPMI medium containing $0.025 \%$ trypsin (w/v) and $0.025 \%$ DNase (w/v) (Sigma Chemical Co., St. Louis, MO). The minced tissue was transferred to an RPMI medium containing one-tenth the previous concentrations of trypsin and DNase, and was mechanically agitated by a trituration process described previously (Campbell et al., 1977). This resulted in a suspension of cell bodies and subcellular material, which was decanted into $4 \mathrm{vol}$ of a solution comprised of Hanks' balanced salt solution (GIBCO no. 310-4170) and fetal calf serum $(80: 20)$ to inactivate the trypsin. The cellular material was then pelleted by centrifugation $(500 \times g$ for $10 \mathrm{~min})$ at $6^{\circ} \mathrm{C}$. The pelleted material was resuspended in $5 \mathrm{ml}$ of the Hanks' solution containing DNase $(0.0025 \% \mathrm{w} / \mathrm{v})$ and was layered onto a preformed $40 \%$ Percoll (Pharmacia, Uppsala) gradient. Centrifugation for $15 \mathrm{~min}$ at $4300 \times g$ resulted in two bands of material. These bands of material were removed, diluted with Hanks' solution, pelleted by centrifugation, and resuspended in $5 \mathrm{ml}$ of Hanks' solution containing $0.0025 \%$ DNase. The material in the upper and lower bands was layered onto $20 \%$ and $60 \%$ preformed Percoll gradients, respectively, and centrifuged as described for the $40 \%$ Percoll gradient. This resulted in a total of five regions where the cellular material was concentrated. Each band of material was removed from the gradient, diluted with Hanks' solution, pelleted by centrifugation, and resuspended in 2 to $20 \mathrm{ml}$ of Hanks' solution. The cellular material in these five fractions was maintained at 2 to $4^{\circ} \mathrm{C}$ until subjected to experimental analysis.

To preform the Percoll continuous density gradients, 9 vol of Percoll were mixed with 1 vol of $10 \times$ Hanks' solution (GIBCO, no. 318 4180). This was then mixed with an appropriate amount of $1 \times$ Hanks' solution so that the final amount of Percoll was either $20 \%, 40 \%$, or $60 \%$. The continuous density gradients were then preformed by centrifugation for $30 \mathrm{~min}$ at $27,000 \times g$ using a fixed angle rotor.

Determination of the initial rate of uptake of amino acids and some relaled melaboliles. In these experiments $50-\mu$ l samples of cellular material containing the equivalent of 5 to $30 \mu \mathrm{g}$ of protein were added to $150 \mu \mathrm{l}$ of an incubation medium containing 0.02 to $0.05 \mu \mathrm{Ci}$ of $\mathrm{a}^{14} \mathrm{C}$ labeled compound or 0.1 to $0.2 \mu \mathrm{Ci}$ of a ${ }^{3} \mathrm{H}$-labeled compound. The compounds tested included $\left[U_{-}^{14} \mathrm{C}\right]-\alpha-$ ketoglutarate $(299 \mathrm{mCi} / \mathrm{mmol}),\left[1-{ }^{14} \mathrm{C}\right]-\alpha$-ketoglutarate (249 $\mathrm{mCi} / \mathrm{mmol}),\left[1-{ }^{14} \mathrm{C}\right]-\mathrm{L}-$ leucine $(57.4 \mathrm{mCi} / \mathrm{mmol})$, [ring-3,5- $\left.{ }^{3} \mathrm{H}\right]$-L-tyrosine $(50.1 \mathrm{Ci} / \mathrm{mmol}),\left[U-{ }^{14} \mathrm{C}\right]-\mathrm{L}-\alpha-$ alanine $(172 \mathrm{mCi} / \mathrm{mmol}),\left[1-{ }^{14} \mathrm{C}\right]$ pyruvate $(8 \mathrm{mCi} / \mathrm{mmol})$, $\left[2-{ }^{14} \mathrm{C}\right]$ pyruvate $(8.2 \mathrm{mCi} / \mathrm{mmol}),\left[U^{14} \mathrm{C}\right]-\mathrm{L}$-glutamate $(276 \mathrm{mCi} / \mathrm{mmol}),\left[U_{-}{ }^{14} \mathrm{C}\right]-\gamma$-aminobutyrate $(203 \mathrm{mCi} /$ $\mathrm{mmol}),\left[4-{ }^{3} \mathrm{H}\right]-\mathrm{L}$-proline $(15.6 \mathrm{Ci} / \mathrm{mmol}),\left[3-{ }^{3} \mathrm{H}\right]-\beta$-alanine $(38 \mathrm{Ci} / \mathrm{mmol}),\left[2{ }^{14} \mathrm{C}\right]$ acetate $(44 \mathrm{mCi} / \mathrm{mmol}),[1,2-$ $\left.{ }^{14} \mathrm{C}\right]$ taurine $(56 \mathrm{mCi} / \mathrm{mmol}),\left[U_{-}{ }^{14} \mathrm{C}\right]$ glycine $(12.9 \mathrm{mCi})$ mmol), $\left[3-{ }^{3} \mathrm{H}\right]-\mathrm{L}$-lysine, all purchased from New England Nuclear (NEN, Boston, MA), and $\left[U_{-}{ }^{14} \mathrm{C}\right]-\mathrm{L}-$ ornithine (200 to $300 \mathrm{mCi} / \mathrm{mmol}$ ) which was purchased from NEN and Amersham Corp. (Arlington Heights, IL).

Unless specified otherwise, the incubation medium was comprised of $\mathrm{NaCl}(120 \mathrm{mM}), \mathrm{KH}_{2} \mathrm{PO}_{4}(3 \mathrm{mM}), \mathrm{MgCl}_{2}(2$ $\mathrm{mM}), \mathrm{CaCl}_{2}(2 \mathrm{mM})$, glucose $(5 \mathrm{mM})$, and was buffered with $\mathrm{NaHCO}_{3}(24 \mathrm{~mm})$. Prior to incubation, the medium was aeraled with a mixture of $\mathrm{O}_{2}: \mathrm{CO}_{2}$ gas $(95: 5)$. The $\mathrm{pH}$ of the medium was 7.3 to 7.4 . Specific concentrations of each compound studied was achieved by adding appropriate amounts of the nonlabeled form (Sigma).

The samples were incubated in polyethylene micro centrifuge tubes $(400 \mu \mathrm{l})$ at $35^{\circ} \mathrm{C}$. The period of incubation was usually $2,4,6$, or $10 \mathrm{~min}$, but in preliminary experiments samples were incubated as long as $20 \mathrm{~min}$ in order to establish the time interval over which the accumulation of radiolabel was linear. For blanks, samples were incubated at 0 to $2^{\circ} \mathrm{C}$, or an amount of the nonradiolabeled form of the test compound was added to the medium to make a total concentration of $10 \mathrm{~mm}$.

Incubation was terminated by transferring the samples to an ice bath. The suspension of cellular material was then pelleted by centrifugation, the supernatant was removed by suction, and the surface of the pellet was washed twice with cold medium. The bottom 2 to $4 \mathrm{~mm}$ of the micro centrifuge tube which contained the pellet was cut off, blotted and placed into a scintillation vial for determination of radioactivity. Radioactivity was determined by scintillation counting at approximately $90 \%$ and $35 \%$ efficiency for ${ }^{14} \mathrm{C}$ and ${ }^{3} \mathrm{H}$, respectively.

Analysis of amino acid content in the five cellular frac- 
tions and cerehellar tissue. A portion (usually $100 \mu \mathrm{l}$ ) of the suspended cellular material, or a tissue homogenate containing 10 to $40 \mu \mathrm{g}$ of protein, was added to $200 \mu \mathrm{l}$ of an acetone, ethanol, $5 \%$ aqueous sulfosalicylic acid (40:40:20) solution and mixed vigorously to extract soluble amino acids. Particulate material was pelleted by centrifugation, and one-half of the sample supernatant was transferred to a test tube and dried. To each dried extract $1 \mu \mathrm{Ci}$ of [ ${ }^{3} \mathrm{H}$ ]DNFB (dinitrofluorobenzene, $24 \mathrm{Ci}$ / mmol; NEN) together with $50 \mathrm{nmol}$ of nonlabeled DNFB (Sigma) dissolved in $20 \mu \mathrm{l}$ of heptane:bromobenzene $(80: 20)$, and $200 \mu \mathrm{l}$ of $\mathrm{K}^{+}$borate buffer $(0.3 \mathrm{M}, \mathrm{pH}=9.0)$ were added. Each tube was capped and incubated for 90 $\min$ at $60^{\circ} \mathrm{C}$ in a covered shaking water bath. After the samples were allowed to cool to room temperature 10 $\mathrm{nmol}$ of standard dinitrophenyl amino acids dissolved in $20 \mu \mathrm{l}$ of $\mathrm{H}_{2} \mathrm{O}$, then $200 \mu \mathrm{l}$ of $1 \mathrm{~N} \mathrm{HCl}$ were added and mixed into each sample. Subsequently, the ether-soluble dinitrophenyl amino acid derivatives were extracted. The ether $(400 \mu \mathrm{l})$ was added, mixed, then removed a total of three times. The combined ether extract was dried, resuspended in $20 \mu$ l of acetone ethanol (50:50), and spotted on Analtech (Newark, DE) Uniplates. The solvent systems used to develop the chromatograms were comprised of ether, ethanol, methanol, and ammonia (50:10:10:4), and ether, chloroform, benzyl alcohol, and acetic acid $(50: 20: 10: 4)$. The chromatograms were developed first in the basic solvent, and for optimal separation the plates were exposed to the vapor for $15 \mathrm{~min}$ before immersing them into the solvent. After development, the portion of the chromatogram containing each amino acid derivative was removed and transferred to a scintillation vial. The amount of ${ }^{3} \mathrm{H}$ and ${ }^{14} \mathrm{C}$ in each sample was determined by scintillation counting. An external standard curve obtained from known amounts of ${ }^{14} \mathrm{C}$-labeled and nonlabeled amino acids, and an internal standard (DL- $\alpha$-aminoadipate) were used to quantify the amounts of each amino acid present in the extract.

Incubation procedure used to examine metabolic activity in the cellular fractions. In these experiments $100 \mu \mathrm{l}$ of the cellular material were mixed with $200 \mu \mathrm{l}$ of incubation medium containing 0.05 to $0.2 \mu \mathrm{Ci}$ of ${ }^{14} \mathrm{C}$-labeled glutamate, glutamine, ornithine, pyruvate or $\alpha$-ketoglutarate, then incubated for either 4 or $10 \mathrm{~min}$ at $35^{\circ} \mathrm{C}$ in a shaking water bath. After incubation the cellular material was pelleted and washed, and subsequently the acid-soluble amino acids were extracted as described above. A portion of the extract from each sample was transferred to a scintillation vial in order to determine the total ${ }^{14} \mathrm{C}$ present. The amount of ${ }^{14} \mathrm{C}$ present in various amino acids was determined by the thin layer chromatographic procedure described above.

Protein determination. Protein was assayed by the BioRad procedure (Technical Bulletin 1051). Bovine $\gamma$-globulin was used as a standard.

Morphological examination of the cellular fractions. The cellular fractions were routinely examined by light microscopy in order to calculate the total number of cell bodies in each fraction. For electron microscopic analysis, samples of the cellular material were pelleted, then resuspended in phosphate-buffered saline (PBS) $(\mathrm{pH} 7.4$, 330 milliosmoles) containing $2 \%$ glutaraldehyde. The fixed material was pelleted, washed three times with PBS, and postfixed with $1 \% \mathrm{OsO}_{4}$ in $0.2 \mathrm{M}$ sym-collidine buffer ( $\mathrm{pH}$ 7.4, 330 milliosmol) for $1 \mathrm{hr}$. After staining overnight with $1 \%$ uranyl acetate, the material was dehydrated with graded ethanol solutions, cleared with propylene oxide, and embedded in Epon 812. Silver sections were made and stained with uranyl acetate and lead citrate.

Calculation of transport kinetic constants. The $K_{\mathrm{m}}$ and $V_{\max }$ values were calculated using a weighted nonlinear regression analysis. This analysis was achieved by use of the Pennzyme computer program (Kohn et al., 1979). Eadie-Hofstee plots of the data indicated that in several instances uptake could have been mediated by two transport systems. In these instances a regression analysis was performed using rate law equations appropriate for uptake mediated by a single system, and by two carrier systems functioning independently. Uptake was judged to be mediated by one carrier or two carriers based on the criteria specified by Kohn et al. (1979).

\section{Results}

Morphological characterization of the five cellular fractions. The approximate percentage of total protein, number of nucleated cells, and prominent morphological features of each fraction are listed in Table I. The cellular

TABLE I

Comparison of cellular material present in the five fractions obtained from the cerebellum of 8-to 14-day-old mice

\begin{tabular}{|c|c|c|c|c|}
\hline $\begin{array}{l}\text { Fraction } \\
\text { Number }\end{array}$ & $\begin{array}{l}\text { Gradient } \\
\text { Location }\end{array}$ & $\begin{array}{c}\text { Protein } \\
(\% \text { of total })^{\alpha}\end{array}$ & $\begin{array}{l}\text { Nucleated } \\
\text { Cells per } \\
\text { Cerebellum }\end{array}$ & $\begin{array}{c}\text { Prominent } \\
\text { Morphological } \\
\text { Characteristics }\end{array}$ \\
\hline 1 & $20 \%$ top & 5 & $0.2 \times 10^{f}$ & $\begin{array}{l}\text { Myelin and other } \\
\text { membranes, } \\
\text { large neuron } \\
\text { cell bodies }\end{array}$ \\
\hline 2 & $20 \%$ middle & 50 & $1 \times 10^{6}$ & $\begin{array}{l}\text { Synaptosomes } \\
\text { and other "cy- } \\
\text { tosomes"c and } \\
\text { cell bodies of } \\
\text { several cell } \\
\text { types }\end{array}$ \\
\hline 3 & $20 \%$ bottom & 5 & $1 \times 10^{6}$ & $\begin{array}{l}\text { Cell bodies from } \\
\text { astrocytes and } \\
\text { several other } \\
\text { cell types }\end{array}$ \\
\hline 4 & $60 \%$ top & 10 & $2 \times 10^{6}$ & $\begin{array}{l}\text { Cell bodies from } \\
\text { astrocytes and } \\
\text { several other } \\
\text { cell types }\end{array}$ \\
\hline 5 & $60 \%$ bottom & 30 & $8 \times 10^{6}$ & $\begin{array}{l}\text { Cell bodies de- } \\
\text { rived primarily } \\
\text { from granule } \\
\text { cells }\end{array}$ \\
\hline
\end{tabular}

${ }^{a}$ Protein values represent the approximate percentage of the amount accounted for in all five fractions. In mice less than 10 days old the percentage in fraction 2 was less then $50 \%$, whereas in mice more than 12 days old the percentage was higher than $50 \%$.

${ }^{b}$ The number of nucleated cell bodies is reported as the approximate number present in each fraction per cerebellum.

"The term "cytosome" refers collectively to membrane-bound entities containing identifiable subcellular organelles such as mitochondria and vesicles. These entities presumably are derived from dendrites, axons, and glial processes in addition to nerve terminals. 
material located in the upper band of the $20 \%$ gradient (fraction 1) was heterogeneous and not dominated by any single entity. Myelin-like membrane and large nucleated cell bodies were prevalent in this fraction (Fig. $1 A$ ), but synaptosomes and other "cytosomes" were also present in this fraction, particularly in mice older than 12 days. The most prevalent entities in the middle band of the $20 \%$ gradient (fraction 2 ) were synaptosomes and other "cytosomes" (Fig. 1B). The amount of material in fraction 2 increased considerably during the 2 nd postnatal week, accounting for less than $10 \%$ of the protein at 8 days of age, but more than $50 \%$ at 14 days. This presumably reflects the rapid proliferation of synapses occurring at this time (Altman, 1972). The cellular material that banded in the most dense region of the $20 \%$ Percoll gradient (fraction 3) was comprised primarily of
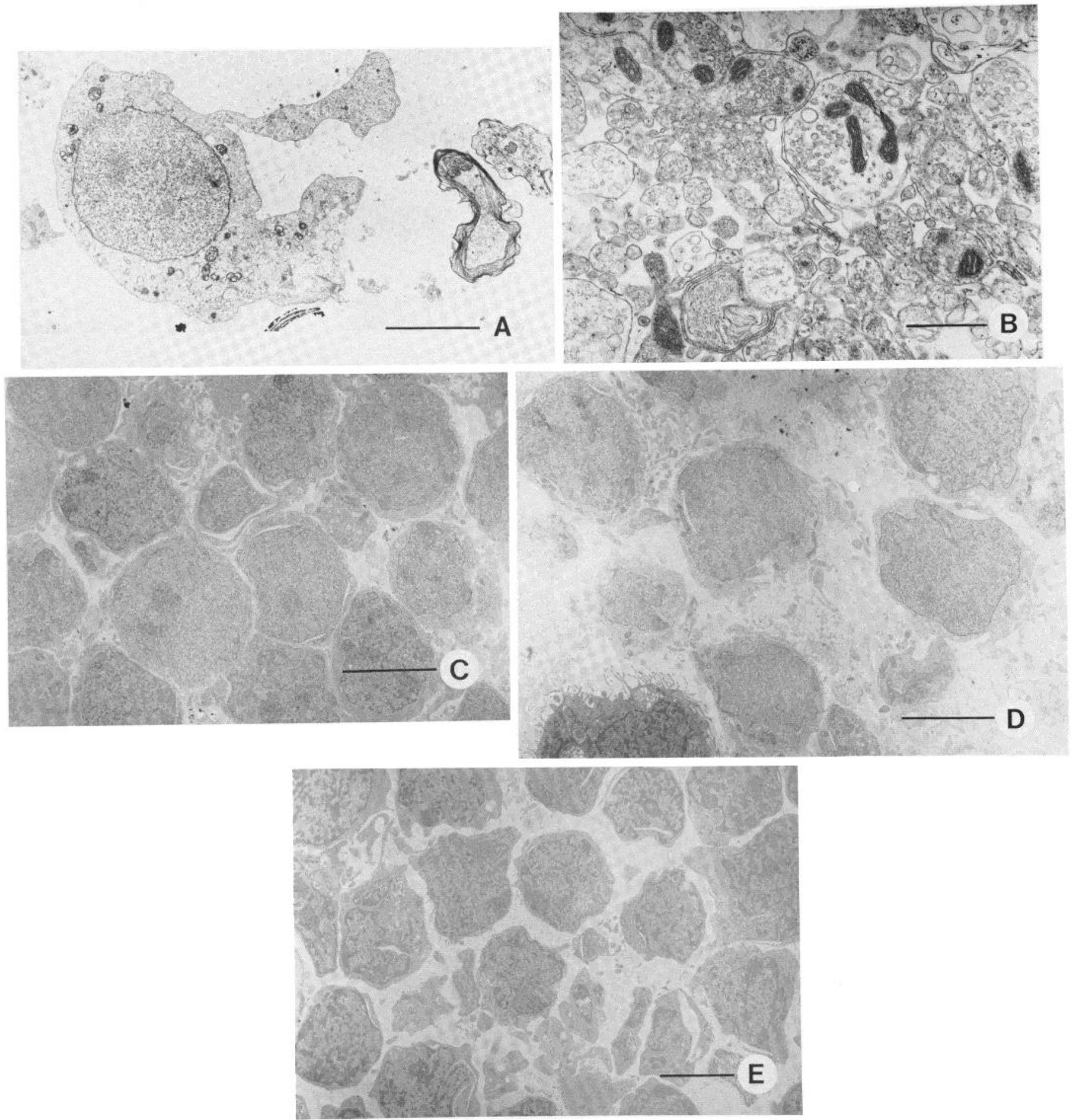

Figure 1. Electron micrographs of cellular material in the five cerebellar fractions. The micrographs are listed alphabetically in correspondence with fractions 1 through 5 in Table I. Each length bar is $5 \mu \mathrm{m}$ except for fraction $2(B)$, which is $1 \mu \mathrm{m}$. 
nucleated cell bodies (Fig. $1 C$ ). This population of cells exhibited a heterogeneous size and morphology, indicating that several cell types were present.

The top band of the $60 \%$ gradient (fraction 4) was comprised almost entirely of nucleated cell bodies (Fig. $1 D$ ). As with fraction 3 , several types of cells were present in this fraction, but in both of these fractions many of the cells exhibited a nuclear morphology characteristic of the Bergmann glial cells. The cellular material in the bottom band of the $60 \%$ gradient (fraction 5 ) was comprised of a nearly homogeneous population of nucleated cell bodies, the size and nuclear morphology of which were characteristic of granule cells. This fraction contained approximately two-thirds of the total number of cells obtained in all five fractions, a result consistent with the prevalent occurrence of granule cells in the cerebellum. The number of cells in this fraction was nearly constant in mice ranging from 8 to 14 days old. Beyond this age the number of cells was appreciably smaller, indicatir ? that fewer cells survived the process used to isolate the cells.

Based upon an analysis of glial fibrillary acidic protein in cells grown in vitro, 40 to $50 \%$ of the cell bodies in fractions 3 and 4 were astrocytes, whereas in fraction 5 approximately $2 \%$ of the cells were astrocytes (Campbell et al., 1977; unpublished observations). Although astrocytes were the most prominent cell type in fractions 3 and 4, these fractions also contained some granule cell bodies, ciliated ependymal cells, oligodendrocytes, and probably microglial, endothelial cells and fibroblasts. Some cell bodies of inhibitory neurons were also presumably present in these fractions; however, the content and synthesis of GABA from various substrates were comparatively low (see below). These observations indicate that fractions 3 and 4 were neuron depleted in addition to being astrocyte enriched.

Uptake of various compounds by the five cellular fractions. In preliminary experiments the uptake of most compounds was linear for at least $4 \mathrm{~min}$. Leucine and tyrosine were exceptions in that the rate of uptake of these amino acids became nonlinear within a 2-min incubation period. Preliminary experiments also revealed that incubation at 2 to $4^{\circ} \mathrm{C}$ affected the uptake of compounds differently. The uptake rate for glutamate, GABA, and $\alpha$-ketoglutarate was reduced to less than $10 \%$ of the rate at $35^{\circ} \mathrm{C}$, whereas the rate of uptake of most other compounds was reduced to 15 to $30 \%$ of that at $35^{\circ} \mathrm{C}$.

In a preliminary study, the effect of trypsin on the rate of uptake was determined. For these experiments the cerebellum of 6 - to 8-day-old mice was used because it was possible to dissociate this tissue without using trypsin. Under the conditions of our experiments, glutamate, GABA, and $\alpha$-ketoglutarate were accumulated at a rate that was 25 to $50 \%$ slower by the trypsin-treated cellular material than by comparable non-trypsin-treated material. However, the uptake of most other compounds was not affected appreciably by trypsin. In agreement with the observation of Wang et al. (1975), trypsin was found to reduce the $V_{\max }$ of glutamate uptake without altering the $K_{\mathrm{m}}$. In other preliminary experiments biochemical data were obtained on cerebellar cellular material of mice ranging in age from newborn to adult. Our results indicated that for mice between 8 and 14 days of age there were no appreciable differences in the uptake of amino acids in each cellular fraction and the nerve terminal fraction when the data were expresed on a milligrams of protein basis. Unless specified otherwise the reported data were obtained from mice between 8 and 14 days of age.

When uptake velocities were determined at a substrate concentration of $8 \mu \mathrm{M}$, most of the compounds studied were taken up at a faster rate by the fraction enriched in synaptosomes (fraction 2) than by the other four fractions (Fig. 2). Based on calculated $K_{m}$ and $V_{\max }$ values this was due primarily to a higher $V_{\max }$ rather than to differences in substrate affinities (Table II). A factor that may have contributed appreciably to the higher uptake capacity by the synaptosome-enriched fraction is the smaller average size of the cellular material in this fraction and the concomitantly higher ratio of cell membrane protein (surface area) to total protein (volume) in this fraction.

Of the four fractions enriched in cell bodies the most obvious comparative differences were the very low relative uptake velocities of GABA and citrate by the fraction enriched in granule cells (fraction 5). For GABA this can be attributed to a very low $V_{\max }$ (Fig. 3, Table II). The small amount of GABA that was accumulated by fraction 5 may have been due almost entirely to the small proportion of astrocytes present in this fraction. The comparatively low uptake of taurine, $\beta$-alanine, glutamate, and $\alpha$-ketoglutarate by the fraction enriched in granule cells (Fig. 2) can also be attributed to a low $V_{\max }$ rather than to differences in $K_{\mathrm{m}}$ values (Table II). A kinetic analysis of the uptake of GABA (Fig. 3) and glutamate (Fig. 4) indicated that carriers with exceptionally high substrate affinities were present in the fraction enriched in astrocyte cell bodies (fractions 3 plus 4). Since fractions 3 and 4 contained several types of non-neuronal cells it is possible that cells other than astrocytes contributed to the high affinity uptake of glutamate and GABA; however, data obtained from experiments using a variety of procedures to study uptake indicate that the uptake of glutamate and GABA by astrocytes exceeds that of other types of non-neuronal cells (Ehinger, 1977; Wilkin et al., 1982).

Amino acid content in the five cerebellar fractions and fresh tissue. Of the nine amino acids measured, only glutamate, aspartate, and GABA exhibited any appreciable differences in content among the five fractions (Fig. 5). Glutamate and aspartate were selectively concentrated in the fraction enriched in nerve terminals (fraction 2), whereas GABA was concentrated in fractions 1 and 2. Another noteworthy result was the presence of some GABA in the fraction enriched in granule cells.

A comparison of the content of amino acids in the five fractions to that in whole cerebellar tissue revealed that the glutamine content decreased considerably during the cellular isolation and fractionation process. Furthermore, there was an apparent decline in the total amount of glutamate and an increase in the total amount of aspar- 


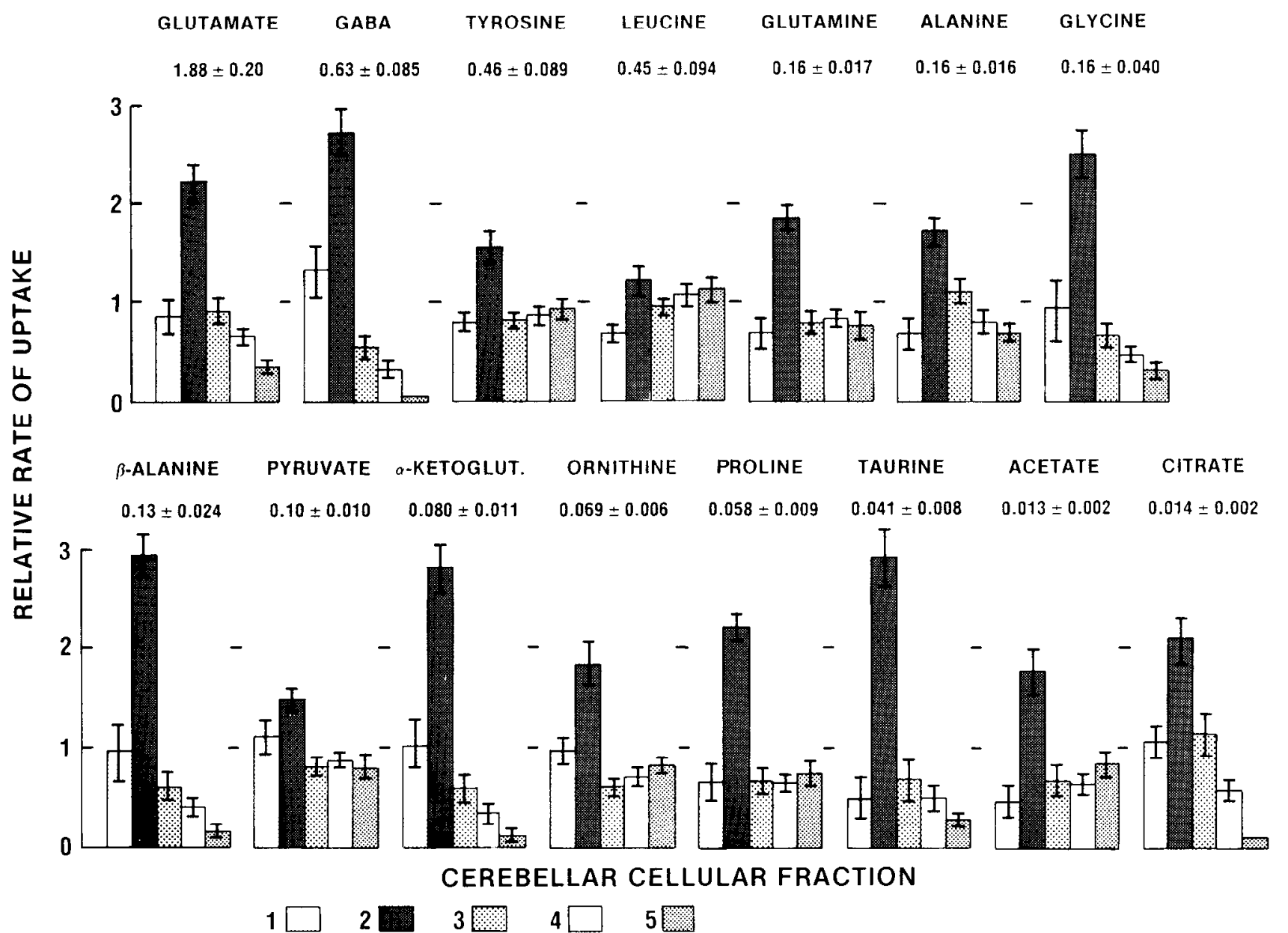

Figure 2. Uptake of 11 amino acids and 1 intermediary metabolites by the five cerebellar fractions. The numbers listed under the name of each compound represent the averaged ( $\left(\right.$ SEM) uptake values of the five fractions in pmol min $\mathrm{mg}^{-1} \mu \mathrm{g}$ protein ${ }^{-1}$. The relative rate of uptake for each fraction is the ratio of uptake values of the fraction specified to the average uptake by the five fractions. These values represent the mean \pm SEM of 6 to 10 experiments, each performed in triplicate. For each compound the initial concentration in the medium was $8 \mu \mathrm{M}$. The incubation period was 4 , 6 , or 10 min except for leucine and tyrosine which were incubated 1 or $2 \mathrm{~min}$.

tate. These changes in amino acid content cannot be attributed solely to a lack of energy substrate because all of the media in which the cellular material was bathed contained glucose at a concentration of $5 \mathrm{~mm}$. The content of other amino acids did not differ appreciably from that in whole tissue.

Metabolism of various compounds by the five cerebellar fractions. As a means of studying some aspects of metabolic activity, we incubated samples of the five cerebellar fractions with several ${ }^{14} \mathrm{C}$-labeled compounds and measured the incorporation of label into various amino acids (Fig. 6). Of particular interest to us was the relative incorporation of label into glutamate and GABA from potential metabolic precursors of these neurotransmitters. Glutamate was labeled extensively in all five fractions when $\left[U^{-}{ }^{14} \mathrm{C}\right]-\alpha$-ketoglutarate, $\left[U^{-1}{ }^{14} \mathrm{C}\right]$ glutamine, and $\left[2-{ }^{14} \mathrm{C}\right]$ pyruvate were supplied as precursors.

Label was incorporated into GABA more readily in the fractions enriched in large cell bodies and nerve terminals than in the remaining three fractions. A comparison of the extent to which label was incorporated into GABA from $\left[U-{ }^{14} \mathrm{C}\right]-\alpha$-ketoglutarate, $\left[U-{ }^{14} \mathrm{C}\right]$ glutamine, $\left[U-{ }^{14} \mathrm{C}\right]$ glutamate, and $\left[2{ }^{14} \mathrm{C}\right]$ pyruvate revealed that $\mathrm{G} \Lambda \mathrm{B} \Lambda \mathrm{rc}-$ ceived label selectively from glutamine and, possibly, from pyruvate. For example, in fraction 2 the ${ }^{14} \mathrm{C}$ dpm in GABA was $8.9 \%(\mathrm{SD}= \pm 1.3 \%, N=4)$ of that in glutamate when $\left[U_{-}{ }^{14} \mathrm{C}\right]$ glutamine was supplied as the source of label, but only $1.2 \%(\mathrm{SD}=0.2 \%, N=4)$ and $1.4 \%(\mathrm{SD}=0.5 \%, N=4)$ of that present in glutamate when $\left[U-{ }^{14} \mathrm{C}\right]$ glutamate and $\left[U{ }^{14} \mathrm{C}\right]-\alpha$-ketoglutarate, respectively, were the source of the label. Statistically, the ratio obtained with glutamine is significantly higher at $p$ $<0.01$. Since the incubation period for pyruvate was 10 min rather than $4 \mathrm{~min}$, the high ratio obtained with this substrate $(7.7 \% \pm 0.6 \%, N=3)$ may be due in part to the longer incubation period. When $\left[U-{ }^{14} \mathrm{C}\right]$-L-ornithine was supplied as a precursor, the amount of label incorporated into GABA was not sufficient to quantitate.

The incorporation of label into glutamine from radiolabeled glutamate, pyruvate, $\alpha$-ketoglutarate, and ornithine was most prominent in the fractions enriched in astrocyte and granule cell bodies (fractions 3, 4, and 5). The accumulation of label in alanine from pyruvate was also most prominent in these fractions. 
TABLE II

Kinetic constants for the uptake of nine amino acids and $\alpha$-ketoglutarate by cerebellar cellular fractions enriched in synaptosomes, astrocytes, and granule cell bodies

The rate at which each compound was accumulated in fraction 2 (synaptosome), fraction 3 plus 4 combined (astrocyte), and fraction 5 was determined over the concentration range specified. The kinetic constants were calculated using the Pennzyme computer program (Kohn et al. 1979). For most compounds Eadie-Hofstee plots of the uptake data appeared to be nonlinear, indicating the uptake may have been mediated by more than one transport system. The asterisk $(*)$ signifies that Eadie-Hofstee plots suggest the possible existence of a transport system that was not verified on the basis of a statistical analysis of the residual errors obtained from the regression analysis. The values represent the mean \pm SD of data from three to six experiments except where noted.

\begin{tabular}{|c|c|c|c|c|c|}
\hline \multirow{2}{*}{ Transporl Substrate } & \multirow{2}{*}{ Cellular Fraction } & \multicolumn{2}{|c|}{$K_{m}(\mu \mathrm{M})$} & \multicolumn{2}{|c|}{$V_{\max }(\mathrm{nmol} / \mathrm{min} / \mathrm{mg}$ of protein $)$} \\
\hline & & 1 & 2 & 1 & 2 \\
\hline Glutamate & Synaptosome & & $6.7 \pm 0.3$ & & $5.10 \pm 0.2$ \\
\hline \multirow[t]{2}{*}{$0.15-20^{\alpha}$} & Astrocyte & $0.14 \pm 0.04$ & $7.2 \pm 1.3$ & $0.20 \pm 0.06$ & $1.60 \pm 0.1$ \\
\hline & Granule Cell & & $4.7 \pm 0.3$ & & $0.63 \pm 0.04$ \\
\hline GABA & Synaptosome & $*$ & $4.3 \pm 0.2$ & $*$ & $3.70 \pm 0.1$ \\
\hline \multirow[t]{2}{*}{$0.15-20$} & Astrocyte & $0.21 \pm 0.06$ & $8.6 \pm 0.8$ & $0.06 \pm 0.01$ & $0.52 \pm 0.04$ \\
\hline & Granule Cell & $0.30 \pm 0.05$ & $8.4 \pm 2.0$ & $0.008 \pm 0.001$ & $0.03 \pm 0.01$ \\
\hline$\beta$-Alanine & Synaptosome & $*$ & $17.3 \pm 0.9$ & $*$ & $1.40 \pm 0.1$ \\
\hline \multirow[t]{2}{*}{$0.01-20$} & Astrocyte & * & $19.6 \pm 7.1$ & * & $0.25 \pm 0.06$ \\
\hline & Granule Cell & & $12.2 \pm 1.3$ & & $0.10 \pm 0.01$ \\
\hline Taurine & Synaptosome & * & $22.2 \pm 1.8$ & * & $0.33 \pm 0.02$ \\
\hline \multirow[t]{2}{*}{$0.5-20$} & Astrocyte & & $13.5 \pm 1.3$ & & $0.05 \pm 0.01$ \\
\hline & Granule Cell & & $7.2 \pm 0.4$ & & $0.01 \pm 0.001$ \\
\hline Lysine & Synaptosome & $1.1 \pm 0.2$ & $134 \pm 6$ & $0.016 \pm 0.003$ & $2.78 \pm 0.08$ \\
\hline \multirow{2}{*}{$0.01-200$} & Astrocyte & * & $85 \pm 12$ & * & $1.17 \pm 0.12$ \\
\hline & Granule Cell & * & $102 \pm 14$ & $*$ & $1.01 \pm 0.10$ \\
\hline Ornithine & Synaptosome & * & $161 \pm 6$ & * & $2.34 \pm 0.11$ \\
\hline \multirow[t]{2}{*}{$0.2-400$} & Astrocyte & $*$ & $120 \pm 8$ & * & $1.01 \pm 0.05$ \\
\hline & Granule Cell & & $109 \pm 4$ & & $0.70 \pm 0.02$ \\
\hline Glutamine & Synaptosome & $11.0 \pm 1.4$ & $232 \pm 19$ & $0.27 \pm 0.05$ & $6.58 \pm 0.19$ \\
\hline $0.5-500$ & Granule Cell & $*$ & $130 \pm 20$ & * & $1.72 \pm 0.11$ \\
\hline Leucine & Synaptosome $e^{b}$ & $10.0 \pm 1.3$ & $814 \pm 239$ & $0.62 \pm 0.07$ & $8.47 \pm 1.46$ \\
\hline \multirow[t]{2}{*}{$5-500$} & Astrocyte $^{b}$ & $53.6 \pm 6.7$ & * & $2.13 \pm 0.14$ & $*$ \\
\hline & Granule Cell & $11.6 \pm 4.2$ & $937 \pm 517$ & $0.75 \pm 0.20$ & $8.06 \pm 2.58$ \\
\hline Tyrosine & Synaptosome ${ }^{b}$ & $10.4 \pm 2.8$ & * & $0.77 \pm 0.14$ & $*$ \\
\hline $5-1000$ & Granule Cell ${ }^{b}$ & $13.2 \pm 3.0$ & * & $0.60 \pm 0.09$ & $*$ \\
\hline$\alpha$-Ketoglutarate & Synaptosome & * & $12.3 \pm 1.0$ & * & $0.42 \pm 0.03$ \\
\hline \multirow[t]{2}{*}{$0.4-20$} & Astrocyte & & $8.0 \pm 0.7$ & & $0.03 \pm 0.002$ \\
\hline & Granule Cell & $*$ & $10.2 \pm 0.9$ & $*$ & $0.01 \pm 0.001$ \\
\hline
\end{tabular}

a These numbers refer to the concentration range studied in micromolar units.

${ }^{b}$ These values were obtained from two experiments.

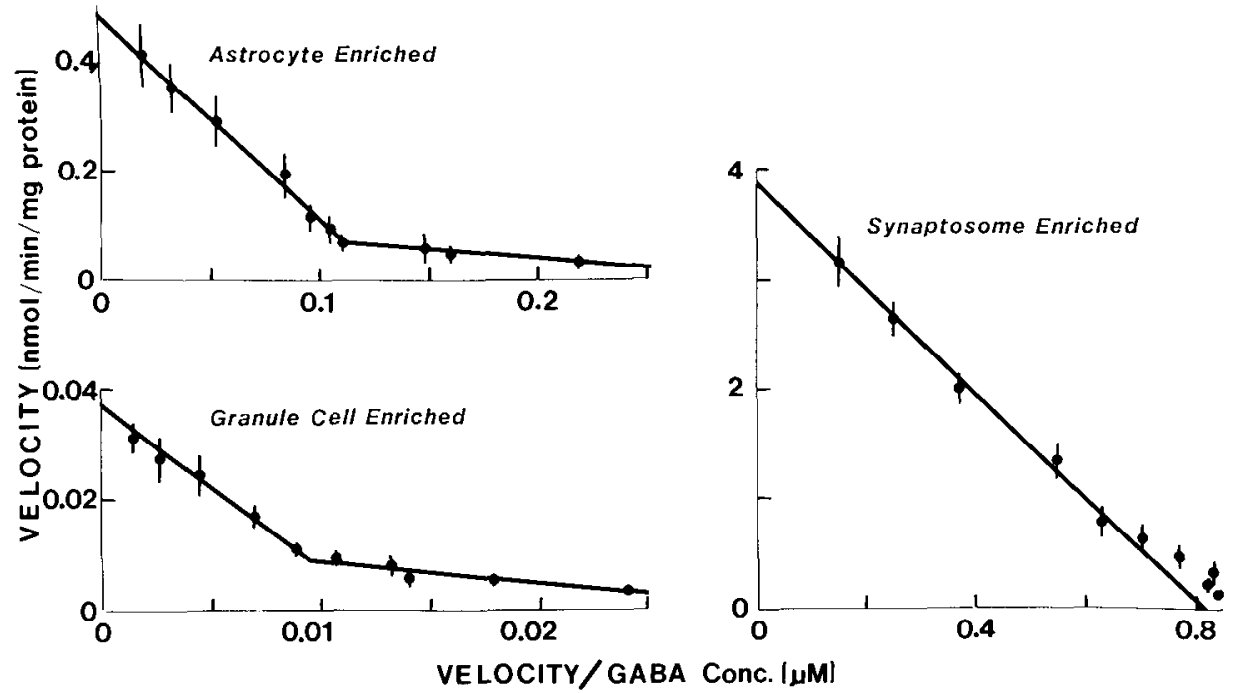

Figure 3. Graphic representation (Eadie-Hofstee plot) of GABA uptake as a function of concentration. Fractions 3 and 4 were combined together to form the astrocyteenriched fraction. The data are the mean \pm SEM of three or four experiments. The lines were drawn based on visual inspection of the data. The calculated $K_{\mathrm{m}}$ and $V_{\max }$ values are reported in Table II. 


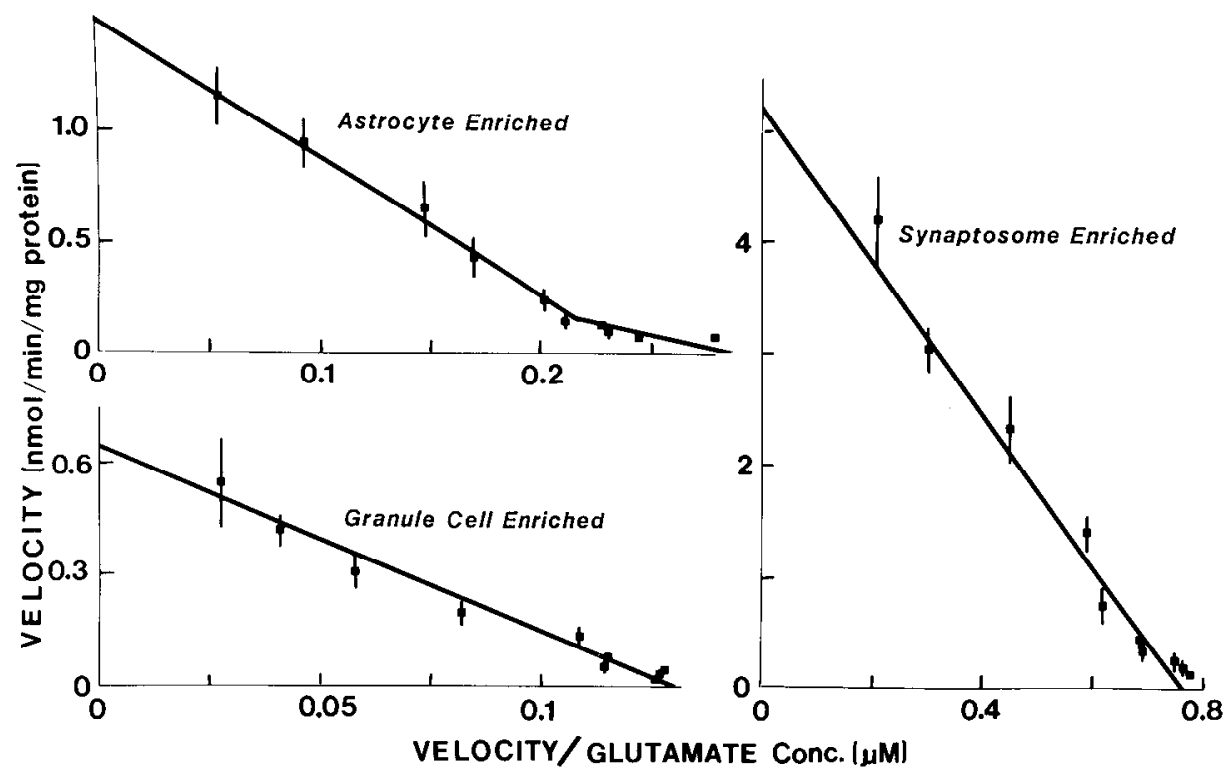

Figure 4. Graphic representation (Eadie-Hofstee plot) of glutamate uptake as a function of concentration. The data are the mean \pm SEM of three to five experiments. The lines were drawn based on visual inspection of the data. The calculated $K_{\mathrm{m}}$ and $V_{\max }$ values are reported in Table II.

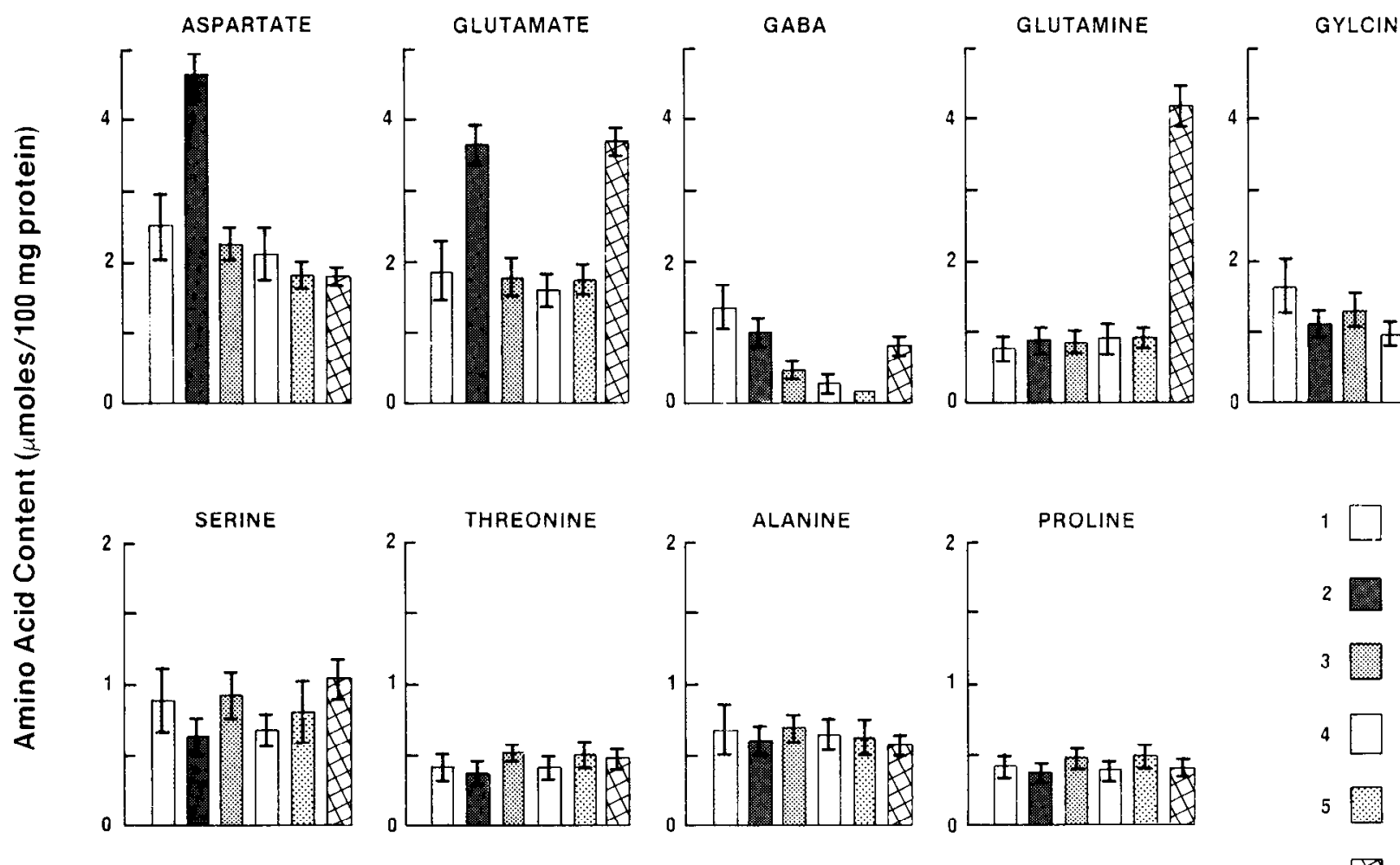

Tissue $\bigotimes$

\section{CEREBELLAR CELLULAR FRACTION}

Figure 5. The content of nine amino acids in the five cerebellar fractions and whole cerebellar tissue of 10- to 14-day-old mice. The data are the mean $( \pm \mathrm{SEM})$ of 8 to 10 experiments except for tissue which is the mean content of four cerebella.

\section{Discussion}

Amino acids as neurotransmitters in the cerebellum. Several of the amino acids investigated in this study are putative neurotransmitters. One criterion of transmitter function stipulates that the candidate should be selec- tively synthesized and concentrated in the neurons from which it is released. Our observation that GABA was concentrated in the fraction enriched in nerve terminals and large cell bodies is consistent with a selective concentration of this amino acid in Purkinje cells and other inhibitory neurons in the cerebellar cortex, all of which 
(U. ${ }^{-1}$ C) $\alpha$-Ketoglutarate
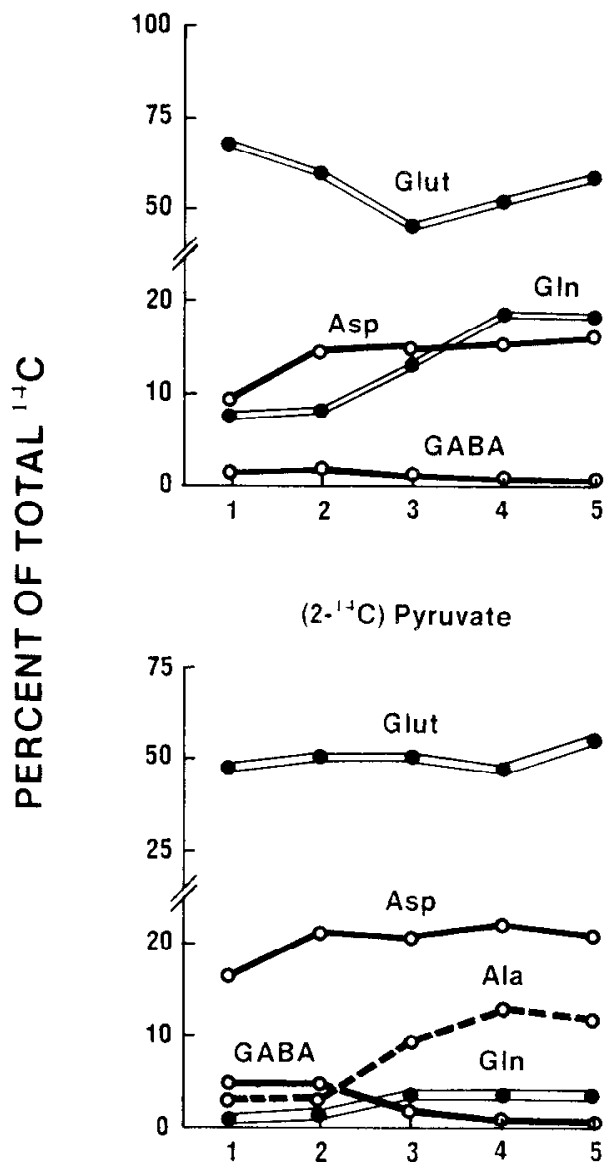

$\left(\mathrm{U}-{ }^{1+} \mathrm{C}\right)$ L-Glutamine

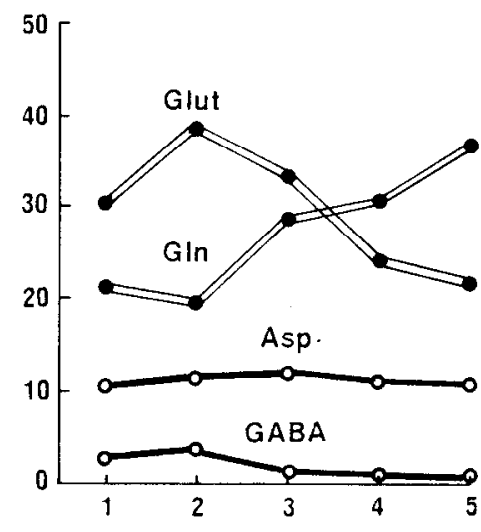

$\left(1-{ }^{1+} \mathrm{C}\right)$ Pyruvate

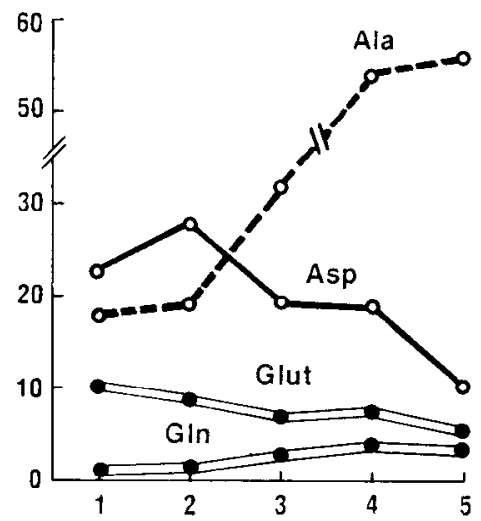

(U. $\left.{ }^{1.4} \mathrm{C}\right)$ L-Glutamate

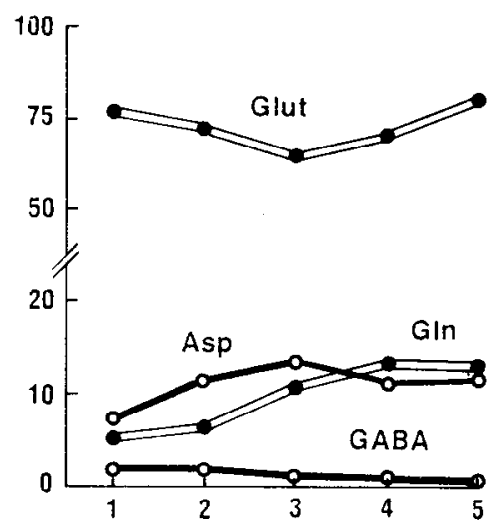

$\left(\mathrm{U}-{ }^{14} \mathrm{C}\right)$ L-Ornithine

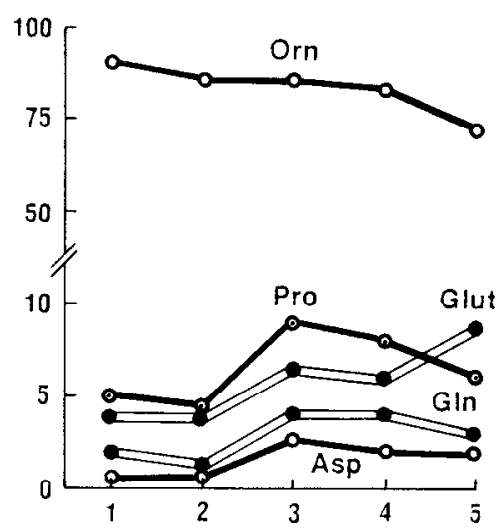

\section{CEREBELLAR CELLULAR FRACTION}

Figure 6. Incorporation of radiolabel into glutamate, GABA, aspartate, and several other amino acids from some possible metabolic precursors of these neurotransmitters. The data are reported as the percentage of total ${ }^{14} \mathrm{C}$ present in the cellular material. Each point is the mean \pm range of two experiments, or the mean \pm SEM of three or four experiments, except the data for fraction 1 using $\left[{ }^{14} \mathrm{C}\right]$ pyruvate, which are the results of single experiments. In this series of experiments $0.1 \mu \mathrm{Ci}$ of $\left[U_{-}{ }^{14} \mathrm{C}\right]$ $\alpha$-ketoglutarate, glutamate, or glutamine was added to the medium and the concentration of each was approximately $1 \mu \mathrm{M}$. For the radiolabeled pyruvate and ornithine, $0.2 \mu \mathrm{Ci}$ was added to the medium and their respective concentrations were $10 \mu \mathrm{M}$ and 2 $\mu \mathrm{M}$. The incubation period was $4 \mathrm{~min}$ for the experiments with $\alpha$-ketoglutarate, glutamate, and glutamine, and 10 min for pyruvate and ornithine.

probably use GABA as a neurotransmitter (Roberts, 1975).

Glutamate is generally considered to be the best candidate for the transmitter released by granule cells in the cerebellum (Young et al., 1971; Hudson et al., 1976; McBride et al., 1976). Our data indicate that glutamate is not selectively concentrated in the granule cell bodies. However, glutamate is concentrated in the nerve terminal-enriched fraction. Since it is likely that a large portion of the material in the nerve terminal-enriched fraction is derived from granule cells, our findings are consistent with the notion that granule cells selectively concentrate glutamate only in the presynaptic terminal. In this same vein is the observation that a population of neurons originating in the dorsal root ganglion, which may utilize glutamate as its neurotransmitter, selectively concentrates this amino acid in the portion of the cell near the central terminals (Johnson and Aprison, 1970).
Our observation that aspartate is concentrated in the nerve terminal-enriched fraction suggests that this amino acid may also function as a neurotransmitter in the cerebellum. Aspartate may function as the transmitter released by climbing fibers (Rea et al., 1978), but another possibility is that aspartate is co-released with glutamate from granule cell terminals. In support of this is the compelling evidence that these amino acids are coreleased from the terminals of excitatory motor neurons in some arthropods (Freeman et al., 1979, 1981). In this context it is of interest that changes in the metabolic and functional state of CNS tissues frequently result in reciprocal alterations in the content of glutamate and aspartate (Siesjo, 1978). Therefore, these amino acids may be co-released in amounts that vary in response to changes in the physiological state of the cells.

Glycine, taurine, proline, and $\beta$-alanine exhibit neuroinhibitory properties when applied to cerebellar neu- 
rons (Kawamura and Provini, 1970; Geller and Woodward, 1974; Felix and Kunzle, 1976; McBride and Frederickson, 1978) and therefore may function as inhibitory neurotransmitters or modulators in the cerebellum. The nearly uniform distribution of proline and glycine among the five fractions does not support a major neurotransmitter role for these amino acids in the cerebellum. The content of $\beta$-alanine was not sufficient for an accurate determination, but in each fraction the amount was about one-tenth that of GABA. Taurine was selectively taken up by the fraction enriched in nerve terminals, but as has been reported previously (Rohde et al., 1979), the rate of uptake was slow in comparison to that of other putative neurotransmitters. Therefore, assuming that the rate of uptake reflects the rate of release from nerve terminals, our data are not supportive of a prominent transmitter function for taurine in the cerebellum.

Metabolic precursors of the neurotransmitter pools of glutamate, aspartate, and GABA. The metabolic precursors utilized to replenish the neurotransmitter pools of glutamate and GABA have not been established. Our observation that comparatively little of the label from $\left[U-{ }^{14} \mathrm{C}\right]$ glutamate was incorporated into GABA is consistent with previous evidence that glutamate is not readily taken up by GABAergic neurons (Storm-Mathisen, 1978) and supports the concept that GABA is derived primarily from a pool of glutamate that is synthesized de novo within GABAergic neurons (Shank and Aprison, 1977; Tapia and Gonzalez, 1978; Roberts, 1981). Current evidence indicates that glutamine, derived at least primarily from astrocytes, serves as a significant metabolic precursor of both the transmitter pool of glutamate and the pool of glutamate converted to GABA (Shank and Aprison, 1981). However, $\alpha$-ketoglutarate, possibly derived from astrocytes (Shank and Campbell, 1981), and ornithine (or arginine) derived from the bloodstream (Roberts, 1981) may also serve as metabolic precursors of these two pools of glutamate. The transport and metabolic data obtained in this study are consistent with the possibility that all three of these metabolites serve as precursors of the transmitter pool of glutamate; however, the pattern of labeling obtained in this study indicates that glutamate is synthesized in nerve terminals more readily from $\alpha$-ketoglutarate and glutamine than from ornithine. Our data further indicate that GABA is synthesized more readily from glutamine than from $\alpha$-ketoglutarate, and that ornithine is metabolized to GABA quite slowly. In contrast to our ornithine data, Yoneda et al. (1982) reported data indicating that ornithine is converted to GABA fairly rapidly under some conditions.

Reuptake into the nerve terminals versus uptake in astrocytes as the mechanism of inactivation for neurotransmitter amino acids. Current evidence indicates that amino acid transmitters are removed from the interstitial fluid either by uptake back into the nerve terminal or uptake into nearby astrocytic elements. Data reported by Young et al. (1974) suggest that glutamate (and aspartate) is transported primarily by carriers located in granule cell nerve terminals, whereas data reported by East et al. (1980), Gordon et al. (1981), and Wilkin et al. (1982) indicate that uptake is mediated primarily by carriers in the membrane of astrocytes. The apparent existence of a transport carrier in the membrane of astrocytes that possesses an exceptionally high affinity for glutamate suggests that these glial cells are ideally suited for maintaining very low extracellular levels of glutamate. The high rate of glutamate uptake by the synaptosome-enriched fraction suggests that the transport carriers in glutamatergic terminals may serve to rapidly remove extracellular glutamate when the concentration exceeds $1 \mu \mathrm{M}$. Hence, the relative uptake by nerve terminals as compared to astrocytes may depend on the experimental conditions used. The vigorous uptake of glutamate by the astrocyte- and nerve terminal-enriched fractions suggests that both of these cellular entities are instrumental in clearing glutamate (and aspartate) from the extracellular fluid. Our results do not provide definitive information regarding the quantitative contribution made by astrocytes to the inactivation of glutamate; however, the high $V_{\text {max }}$ of uptake by the nerve terminalenriched fraction does not support the concept that glutamate is inactivated primarily by uptake into astrocytes.

Evidence regarding the role of astrocytes in the inactivation of GABA is also somewhat conflicting. Metabolic studies indicate that exogenously supplied GABA is selectively metabolized to glutamine in CNS tissue (Berl and Clarke, 1969). Because the synthesis of glutamine appears to be localized primarily to astrocytes (Norenberg, 1979) these metabolic data suggest that in intact tissue, exogenous GABA may be selectively taken up by these cells. Furthermore, studies using astrocyteenriched preparations have generally indicated that these cells take up GABA vigorously (Henn and Hamberger, 1971; Burry and Lasher, 1975; Lasher, 1975). In contrast, the results of autoradiographic studies indicate that in most CNS regions GABA is accumulated predominantly in GABAergic nerve terminals (Iversen, 1972; Kelly and Dick, 1975; Sterling and David, 1980), although some exceptions to this have been reported (Schon and Kelly, 1974). The apparent discrepancy in these observations may be due to a difference in the turnover rate of GABA in astrocytes as compared to GABAergic nerve terminals. The content of GABA in astrocytes is low, but the activity of GABA transaminase is high (Roberts, 1975); hence, the turnover of GABA in these cells should be quite fast. Therefore, in a pulse label experiment using $\left[{ }^{3} \mathrm{H}\right] \mathrm{GABA}$ the ${ }^{3} \mathrm{H}$ should be rapidly incorporated into water and lost from these cells, whereas the GABA accumulated by GABAergic nerve terminals may enter into a large endogenous pool of GABA that has a comparatively long metabolic half-life. In most reported autoradiographic studies the elapsed time between the presentation of $\left[{ }^{3} \mathrm{H}\right] \mathrm{GABA}$ and tissue fixation was relatively long (>30 min); hence, most of the label accumulated by astrocytes may have been lost due to metabolic turnover. As noted previously for glutamate the apparent existence of a carrier in the membrane of astrocytes with an exceptionally high affinity for GABA indicates that the primary function of these carriers may be to maintain this neurotransmitter at very low steady-state levels in the extracellular fluid.

Metabolic compartmentation in CNS tissues. An unu- 
sual metabolic characteristic of CNS tissues is that many, but not all, metabolically active compounds are preferentially converted to glutamine as compared to glutamate (Berl and Clarke, 1969). Conceptually this implies that cellular compartments with distinctly different biochemical properties exist in CNS tissues (Berl and Clarke, 1969; Van den Berg, 1970). The biochemical basis and physiological significance of this compartmentation are not fully understood, but one important biochemical factor may be the cellular localization of glutamine synthetase. Immunocytochemical studies by Norenberg (1979) indicate that this enzyme is localized almost exclusively in astrocytes. This appears to be in partial conflict with our results, since we found glutamine labeling to be comparatively high in the fraction enriched in granule cell bodies. Other investigators have reported previously that fractions enriched in neuron cell bodics contain a comparatively high level of glutamine synthetase activity (Piddington, 1977; Ward and Bradford, 1979; Weiler et al., 1979). The activity of glutamine synthetase increases 5 - to 10 -fold during maturation (Berl and Clarke, 1969). A possible explanation that can account for the apparent discrepancy between the immunocytochemical and biochemical data is that the increase in activity may occur only in astrocytes, and the glutamine synthetase within neurons may be restricted to the cell nucleus.

One possible reason that certain metabolic substrates are selectively metabolized to glutamine in CNS tissues is that they are transported only into the compartments containing glutamine synthetase. Of the compounds we studied, several are known to be selectively metabolized to glutamine by intact CNS tissues. These include citrate, acetate, proline, $\alpha$-ketoglutarate, leucine, GABA, and glutamate. Although the apparent existence of very high affinity carriers for GABA and glutamate in the membrane of astrocytes suggests that these compounds could be selectively transported into astrocytes at very low substrate concentrations, our data provide no evidence that most of the other metabolites that arc preferentially metabolized to glutamine are selectively accumulated by astrocytes. Our data therefore indicate that metabolic compartmentation cannot be due primarily to a localization of transport carriers in the membrane of astrocytes. Our data cannot exclude the possibility that intact CNS tissues are structurally arranged in a way that promotes a selective uptake by astrocytes when these substrates are supplied exogenously.

\section{References}

Altman, J. (1972) Postnatal development of the cerebellar cortex in the rat. J. Comp. Neurol. 145: 353-397.

Aprison, M. H., E. C. Daly, R. P. Shank, and W. J. McBride (1976) Neurochemical evidence for glycine as a transmitter and a model for its intra-synaptosomal compartmentation. In Metabolic Compartmentation and Neurotransmission, S. Berl, D. D. Clarke, and D. Schneider, eds., pp. 37-63, Plenum Press, New York.

Berl, S., and D. D. Clarke (1969) Metabolic compartmentation of glutamate in the CNS. In Handbook of Neurochemistry, A. Lajtha, ed., Vol. 1, pp. 168-197, Plenum Press, New York.

Burry, R. W., and R. S. Lasher (1975) Uptake of GABA in dispersed cell cultures of postnatal rat cerebellum: An elec- tron microscope autoradiographic study. Brain Res. 88: 502507.

Campbell, G. LeM., M. Schachner, and S. O. Sharrow (1977) Isolation of glial cell enriched and depleted populations from mouse cerebellum by density gradient centrifugation and electronic cell sorting. Brain Res. 127: 69-86.

Curtis, D. R., and G. A. R. Johnston (1974) Amino acid transmitters in the mammalian central nervous system. Ergeb. Physiol. 69: 97-188.

Davidson, N. (1976) Neurotransmitter Amino Acids, Academic Press, London.

East, J. M., G. R. Dutton, and D. N. Currie (1980) Transport of GABA, $\beta$-alanine and glutamate into perikarya of postnatal rat cerebellum. J. Neurochem. 34: 523-530.

Ehinger, B. (1977) Glial and neuronal uptake of GABA, glutamic acid, glutamine and glutathione in the rabbit retina. J. Exp. Eye Res. 25: 221-234.

Felix, D., and H. Kunzle (1976) The role of proline in nervous transmission. Adv. Biochem. Psychopharmacol. 15: 165-173.

Freeman, A. R., R. P. Shank, J. Kephart, M. Dekin, and M. Wang (1979) Modulation of transmission at a glutamate synapse. J. Physiol. (Paris) 75: 605-610.

Freeman, A. R., R. P. Shank, J. Kephart, M. Dekin, and M. Wang (1981) A model for excitatory transmission at a glutamate synapse. in Glutamate as a Neurotransmitter, G. DiChiara and G. I. Gessa, eds, pp. 227-243, Raven Press, New York.

Geller, H. M., and D. J. Woodward (1974) Responses of cultured cerebellar neurons to iontophoretically applied amino acids. Brain Res. 74: 67-80.

Gordon, R. D., G. P. Wilkin, A. Hunt, A. J. Patel, and R. Balazs (1981) Glutamate high affinity uptake and metabolizing enzymes in cerebellar cells. Trans. Am. Soc. Neurochem. 12: 377.

Henn, F. A., and A. Hamberger (1971) Glial cell function: Uptake of transmitter substances. Proc. Natl. Acad. Sci. U. S. A. 68: 2686-2690.

Hudson, D. B., T. Valcana, G. Bean, and P. S. Timiris (1976) Glutamic acid: A strong candidate as the neurotransmitter of the cerebellar granule cell. Neurochem. Res. 1: 73-81.

Iversen, L. L. (1972) The uptake, storage, release and metabolism of GABA in inhibitory nerves. In Perspectives in Neuropharmacology, S. H. Snyder, ed., pp. 75-111, Oxford University Press, London.

Johnson, J. L., and M. H. Aprison (1970) The distribution of glutamic acid, a transmitter candidate, and other amino acids in the dorsal sensory neuron of the cat. Brain Res. 24: 285292.

Kawamura, H., and L. Provini (1970) Depression of cerebellar Purkinje cells by microiontophoretic application of GABA and related amino acids. Brain Res. 24: 293-304.

Kelly, J. S., and F. Dick (1975) Differential labeling of glial cells and GABA-inhibitory interneurons and nerve terminals following microinjection of ${ }^{3} \mathrm{H}-\beta$-alanine, ${ }^{3} \mathrm{H}$-DABA and ${ }^{3} \mathrm{H}$ GABA into single folia of the cerebellum. Cold Spring Harbor Symp. Quant. Biol. 40: 93-106.

Kohn, M. C., L. E. Menten, and D. Garfinkel (1979) A convenient computer program for fitting enzymatic rate laws to steady state data. Comput. Biomed. Res. 12: 461-469.

Krnjevic, K. (1974) Chemical nature of synaptic transmission in vertebrates. Physiol. Rev. 54: 418-540.

Lasher, R. S. (1975) Uptake of GABA by neuronal and nonneuronal cells in dispersed cell cultures of postnatal rat cerebellum. J. Neurobiol. 6: 597-608

McBride, W. J., and R. C. A. Frederickson (1978) Neurochemical and neurophysiological evidence for a role of taurine as an inhibitory neurotransmitter in the cerebellum of the rat. In Taurine in Neurological Disorders, A. Barbeau and R. J. Huxtable, eds., pp. 415-427, Raven Press, New York. 
McBride, W. J., N. S. Nadi, J. Altman, and M. II. Aprison (1976) Effects of selective doses of $x$-irradiation on the levels of several amino acids in the cerebellum of the rat. Neurochem. Res. 1: 141-152.

Norenberg, M. D. (1979) The distribution of glutamine synthetase in the rat central nervous system. J. Histochem. Cytochem. 27: 756-762.

Piddington, R. (1977) Subcellular distribution of glutamyltransferase activities in embryonic cerebral hemispheres. Brain Res. 128: 505-514.

Rea, M. A., W. J. McBride, and B. H. Rohde (1980) Regional and synaptosomal levels of amino acid neurotransmitters in the 3-acetylpyridine deafferentated rat cerebellum. J. Neurochem. 34: 1106-1108.

Roberts, E. (1975) GABA in nervous system function-An overview. In The Nervous System. Vol. 1: The Basic Neurosciences, D. B. Tower and R. O. Brady, eds., pp. 541-552, Raven Press, New York.

Roberts, E. (1981) Strategies for identifying sources and sites of formation of GABA-precursor or transmitter glutamate in the brain. In Glutamate as a Neurotransmitter, G. DiChiara and G. L. Gessa, eds., pp. 91-102, Raven Press, New York.

Rohde, B. H., M. A. Rea, J. R. Simon, and W. J. McBride (1979) Effect of X-irradiation induced loss of cerebellar granule cells on the synaptosomal levels and high affinity uptake of amino acids. J. Neurochem. 32: 1431-1435.

Schon, F., and J. S. Kelly (1974) The characterization of $\left[{ }^{3} \mathrm{H}\right]$ GABA uptake into the satellite glial cells of rat sensory ganglion. Brain Res. 66: 289-300.

Shank, R. P., and M. H. Aprison (1977) Glutamine uptake and metabolism by the isolated toad hrain: Fvidence pertaining to its proposed role as a transmitter precursor. J. Neurochem. 28: 1189-1196.

Shank, R. P., and M. H. Aprison (1981) Present status and significance of the glutamine cycle in CNS tissues. Life Sci. 28: 837-842.

Shank, R. P., and G. LeM. Campbell (1981) Avid Na ${ }^{+}$-dependent, high-affinity uptake of alpha-ketoglutarate by nerve terminal enriched material from mouse cerebellum. Life Sci.
28: $843-850$.

Siesjo, B. J. (1978) Brain Energy Metabolism, John Wiley \& Sons, Inc., New York.

Sterling, P., and T. L. David (1980) Neurons in cat lateral geniculate nucleus that concentrate exogenous $\left[{ }^{3} \mathrm{H}\right]$ aminobutyric acid (GABA). J. Comp. Neurol. 192: 692-737.

Storm-Mathisen, J. (1978) Localization of transmitter amino acids: application to hippocampus and septum. In NATO Advanced Study Institutes Series. Amino Acids as Chemical Transmitters, F. Fonnum, ed., Vol. 16: pp. 155-173, Plenum Press, New York.

Tapia, R., and R. M. Gonzalez (1978) Glutamine and glutamate as precursors of the releasable pool of GABA in brain cortex slices. Neurosci. Lett. 10: 165-169.

Van den Berg, C. J. (1970) Glutamate and glutamine. In Handbook of Neurochemistry, A. Lajtha, ed., Vol. 3, pp. 514-544, Plenum Press, New York.

Wang, Y. J., J. W. Gurd, and H. R. Mahler (1975) Topography of synaptosomal high affinity uptake systems. Life Sci. 17: 725-734.

Ward, H. K., and H. F. Bradford (1979) Relative activities of glutamine synthetase and glutaminase in mammalian synaptosomes. J. Neurochem. 33: 339-342.

Weiler, C. T., B. Nystrom, and A. Hamberger (1979) Glutaminase and glutamine synthetase activity in synaptosomes, bulk isolated glia, and neurons. Rrain Res. 160:539-543.

Wilkin, G. P., J. Garthwaite, and R. Balazs (1982) Putative amino acid transmitters in the cerebellum. II. Electron microscopic localization of transport sites. Brain Res. 244: 69 80.

Yoneda, Y., E. Roberts, and G. W. Dietz, Jr. (1982) A new synaptosomal biosynthetic pathway of glutamate and GABA from ornithine and its negative feedback inhibition by GABA. J. Neurochem. 38: 1686-1694.

Young, A. B., M. L. Oster-Granite, R. M. Herndon, and S. H. Snyder (1974) Glutamic acid: Selective depletion by viral induced granule cell loss in hamster cerebellum. Brain Res. 73: $1-13$. 